\title{
Agricultural legislation and its impact on Economic conditions in Africa during the Roman era 146 BC- 284 AD
}

"In light of archaeological resources"

Dr. Salma Mohammed Bakr Husawi

\section{Abstract:}

This paper presents a critical analytical study of agricultural legislation in the African state under Roman rule, with a review of the most important economic features of the state, and the role played by Romanian politics in the development of African economy.

The Roman conquest of Africa in $146 \mathrm{BC}$ brought great changes in various economic conditions in Africa, whether in agriculture, industry or commerce, However, African agriculture was the most economic field that experienced changes, where the Roman made several changes, regarding agricultural land-use and the expansion of agriculture and development of management and division into several types according to quality and area, as well as the development of land survey and irrigation systems, through a set of agricultural legislations regulating agriculture and production relations. This agricultural policy resulted in other changes in the fields of industry and trade, which have been largely related to agricultural developments and have relied heavily on their products.

The importance of Africa in the Romanian economy: after the Romans opened Africa in 146 BC. The Roman followed the policy of imposing control over occupied African territory, as a public property of the Roman people Ager Publicus Popli

\footnotetext{
- Assistant Professor, Department of History Faculty of Arts - King Saud University shosawi@ksu.edu.sa
} 
romani from the perspective of the Roman law, the Roman administration has expropriated the ownership of African lands from indigenous peoples and redistribution to the Roman settlers.

Not only was that done by appropriating fertile lands but also pastoral lands and forests, and creating new administrative sections, until Roman Africa became a province completely different from the Punic Africa after the fall of Carthage, turning it into Romanian control. The Roman occupation of Africa has been associated with economic and social problems in Rome and Italy and the reform movement by the Gracos' brothers, where the People's Movement considered settlement and the distribution of land to the poor Latin and Italians a solution to the social problems that emerged in Rome as a result of the destruction on the Italian territory. The populist view led to a state of boiling and conflict between the aristocracy and the People's Movement. In order to control African territory In $123 \mathrm{BC}$, the aristocraticpopular struggle began on the land of Africa when Giacos Gracos 163-133 BC and succeeded in issuing the Rubros Law known as Lex Rubria. It came in favor of the proletariat where the law allocates a large area of land distributed to six thousand Romans by 50 hectares per person at the expense of land owners. The enactment of that law had brought about the Roman aristocracy unity against Jayos Gracos and his brother. After violent confrontations, the aristocracy regained control of the great monarchy and the conflict led to the deaths of the Gracos. Later, this conflict determined the fate of African territory, where the aristocrats of the Senato Council controlled the large monarchies. They preferred to hire people to bring Italians, and only a very little remained in the hands of the Romanian proletariat

\section{Keywords:}

Roman Era, Legislation, Economy, Africa, Agricultural, Rome, Impact 
The authors extend their appreciation to the Deanship of Scientific Research at King Saud University for funding this work through research project No. R5-16-01-37

The Roman conquest of Africa in $146 \mathrm{BC}$ brought great changes in various economic conditions in Africa, whether in agriculture, industry or commerce. However, African agriculture was the most economic field that experienced changes, where the Roman made several changes, regarding agricultural landuse and the expansion of agriculture and development of management and division into several types according to quality and area, as well as the development of land survey and irrigation systems, through a set of agricultural legislation regulating agriculture and production relations. This agricultural policy resulted in other changes in the fields of industry and trade, which have been largely related to agricultural developments and have relied heavily on their products.

\section{The problem of the research}

This research seeks to study legislation related to agriculture in the state of Roman Africa, and the extent of its impact on the economic situation in this state. This is done by reading the archaeological remains of the legal texts dominated by the legislation and the attempt to extrapolate and analyze the subject of the study to examine the effectiveness of this legislation and the extent of application in the African mandate.

\section{The aim of the research}

This paper presents a critical analysis study of agricultural legislation in the African state under Roman rule, with a review of the most important economic features of the state, and the role played by Romanian politics in the development of the African economy.

By answering the following questions

1. What role did Africa play in the general Roman economy? 
2. To what extent did the Romans succeed in improving the conditions of the African economy?

3. What are the most important agricultural laws issued to improve the conditions of agriculture?

4. What are the objectives of the Romanian government of these laws?

5. Has the Romanian government succeeded in applying these laws to the agricultural community?

6. To what extent has agricultural legislation left its impact on the African economy?

\section{Research Methodology}

This research is based on descriptive analytical approach, which is based on reviewing, describing and analyzing the legal texts, a historical analysis to extrapolate their objectives, knowing their items, and analyzing and critiquing their contents and their role in influencing the general agricultural situation in the state of Africa.

The importance of Africa in the Romanian economy:

After the Roman opened Africa 146 BC., the Roman followed the policy of imposing control over occupied African territory as a public property of the Roman people Ager Publicus Popli romani from the perspective of the Roman law. The Roman administration has expropriated the ownership of African lands from indigenous peoples and made redistribution to the Roman settlers. This was done not only by appropriating fertile lands but also pastoral lands and forests, creating new administrative sections, until the Roman Africa became a province completely different from the Punic Africa after the fall of Carthage and turn it into Romanian control ${ }^{(1)}$.

\footnotetext{
(1) Hugoniot, ch, rome en Afrique, de la chute de Carthage aux débuts de la conquite arabe, Coll. Champs Universite, Flammarion 2000, pp. 22, 23.
} 
The Roman occupation of Africa has been associated with economic and social problems in Rome and Italy and the reform movement by the Gracos' brothers, where the People's Movement considered settlement and distribution of land to the poor Latin and Italians a solution to the social problems that emerged in Rome as a result of the destruction on the Italian territory. The populist view led to a state of boiling and conflict between the aristocracy and the People's Movement in order to control African territory ${ }^{(2)}$.

In $123 \mathrm{BC}$, the aristocratic-popular struggle began on the land of Africa when Giacos Gracos 163-133 BC succeeded in issuing the Rubros Law known as Lex Rubria. It came in favor of the proletariat where the law allocates a large area of land distributed to six thousand Romans by 50 hectares per person at the expense of land owners. The enactment of that law had brought about the Roman aristocracy unity against Jayos Gracos and his brother. After violent confrontations, the aristocracy regained control of the great monarchy, and the conflict led to the deaths of the Gracos. Later, this conflict determined the fate of African territory, where the aristocrats of the Senato Council controlled the large monarchies. They preferred to hire people to bring Italians, and only very little remained in the hands of the Romanian proletariat ${ }^{(3)}$.

The victory of the Roman aristocracy resulted in the determination of the fate of African territory throughout the republican era with respect to land ownership, where the aristocracy enjoyed great ownership. It was followed by the Numidian throne, which was given by the Roman administration to the best land to show good intentions towards it, then in third

\footnotetext{
(2) Akoun, Mohamed El Arabi, Economy and Society in Ancient North Africa, University Press, Algeria, 2008, pp. 79, 80; Jamal Mokhtar, The History of Africa, Volume II, John A. Afrik Publishing House, UNESCO, 1985, p. 487.

${ }^{(3)}$ Carcopino, J., L'aptitude d'assimilation de Berberes á la Civilisation d'après L'histoire ancienne de Afrique du Nord, in VIII e congres Volte, 1938, pp. 11-13.
} 
place the Free Cities got part of the territory rewarded for supporting Rome against Carthage. During the Roman era, the imperial house was replaced by the aristocracy and the emperors received one sixth of the African lands to benefit from their revenues. This was followed by the territory of the aristocracy, then the lands of the municipalities that were distributed to the Roman who have Romanian citizenship, and finally the territory of the African tribes and these have been distributed to the people without recognition of ownership ${ }^{(4)}$.

Through that it has become clear the importance of African lands for the Roman who initiated the expropriation, control, division and exploitation of property as one of the most important sources of wealth and the guaranteed path of investment. Over time, these lands became the most important sources of securing Rome, because of their significance in filling Rome's needs of grain and various crops. The Romanian administration worked on its comprehensive exploitation, increasing its productivity and developing it continuously ${ }^{(5)}$.

The Romanian administration then began land surveying of Centuria in order to recognize the value of the land and its revenues by dividing the land into equal units in the area of 50 hectares. The survey began in $146 \mathrm{BC}$ and continued throughout Roman rule of Africa, but it was built on fertile cultivable land. Rome was not interested in uncultivated land known as Subsiciva, which is not suitable for wheat; the most important crop that Rome was expecting from Africa ${ }^{(6)}$.

\footnotetext{
(4) Shneiti, Mohamed Bashir, Economic and Social Changes in Morocco during the Roman Occupation, National Book Foundation, Algeria, 1984, p. 68; Aqoun, Muhammad al-Arabi, op. Cit., P. 81.

(5) Picard, Ch, La Civilisation de L'Afrique Romanie, 2 edition, Paris, 1990, pp. 94, 95; See also: Worth, Charles, The Roman Empire, translated by Ramzi Abdo Girgis, Family Library, Cairo, 1999, p. 80.

(6) Chevalier, R., la centuriation Romaine et la mise en valeur des sols aans la province d'Afrique, Geog 22 annee, Sept. - Oct., 1958, pp. 150-152; Picard (Ch) et Rouge, J. Textes et documents Relatives a la vie economique et sociale dans L'empire Romaine, Paris, 1969, p. 217.
} 
The Roman showed great interest in the cultivation of wheat in the state of Africa in order to compensate the shortage of wheat production in the Italian territories. Roman policy also relied heavily on granting free wheat to the public and mobs in Rome for the sake of maintaining control over them. The common in Rome was accustomed to these gifts of wheat, which was used in various types of Roman foods. The Roman recognition of the importance of African wheat resulted in increased interest in expansion of its cultivation, allocating administrative staff to harvest and store the wheat in the grain stores and then move it to Rome to supply Rome with the food it needs.

The words of Julius Caesar during his celebration of victory in Africa expressed Roman interest in African wheat when he said: 'I have added to the property of the Roman people a state that can supply Rome with the wheat it needs.' At this time, approximately one hundred and fifty thousand of the public in Rome got free wheat either from Egypt or from Africa ${ }^{(7)}$.

But why has Rome shown great interest in Africa's wheat and not only Egypt's wheat? In fact, the wheat of Egypt was not enough for the Roman citizens after the Italians were emigrating to Rome, as well as, the multiplicity of revolutions that posed a threat to the arrival of the wheat to Italy, so the Emperors have always sent armies to Africa to keep the wheat and prevent it from falling into the hands of the rebels, exposing Rome to definite famine ${ }^{(8)}$.

The number of beneficiaries in Rome of free wheat has increased thereafter to 200 thousand at the beginning of the Imperial age, at a time when Italian territory was helpless about

\footnotetext{
(7) Decret, F \& Fanter, M. L'Afrique du Nord dans L'antiquite des Orgines au Vosicle, Payot, Paris, 1981, p. 213; Picard (Ch), La Civilisation, op. cit., p. 70; Bloch, G., La Republique romaine, les Confilits Politiques et Sociaux, Paris, 1922, p. 151.

${ }^{(8)}$ Bloch, G., op. cit., p. 151; Decret, F \& Fanter, M. op. cit., p. 214.
} 
extending Rome enough to these mouths that are gradually increasing because of the socio-economic crisis that has pushed many Italians farmers to migrate from various localities of Italy to Rome to hang around in their streets ${ }^{(9)}$.

Thus, African wheat was important in the Roman economy and politics, prompting the Roman to expand cultivation until the African wheat supply for Rome rose to from 840 thousand kantars in the era of Julius Caesar to one million, two hundred thousand quintals during the era of Emperor Nero (54-68AD), which represents two thirds of the needs of Rome of wheat in the first century A. $\mathrm{D}^{(10)}$.

During the second century, the place of Africa in the Roman economy has evolved dramatically, as the Roman view of this state has changed, as the most important sources of wheat in the first century A.D. to include the possibility of an expansionary agricultural policy, where there was a need to increase production and land-use other than merely planting trees. Hence, due to the development of African agriculture and expansion of North and South Africa, agriculture has covered all the fertile and unfertile lands of Africa, and wheat has continued to grow in fertile land while uncultivated, marshes and pastoral lands have been exploited in the planting of trees, so that African land has become an essential pillar in the cultivation of olive trees and vineyards, which are the most important sources of oil and wine extraction $^{(11)}$.

\footnotetext{
${ }^{(9)}$ Picard (Ch), La Civilisation, op. cit., p. 70; Bloch, G., op. cit., p. 151.

${ }^{(10)}$ Picard, (Ch), Neron et la ble. D'Afrique, Revue les cahiers de Tunisie, T. IV, 1956, pp. 164-166.

${ }^{(11)}$ Bourgarel - Musso, A., Recharche économique sur l'Afrique Romaine, Revue Africaine, T. 75, 1934, p. 366; Maurice, S., et Tronoy, A., la Mediterranée antique IV, Siecle av. J. C., III, pp. 68-69, Ca.
} 


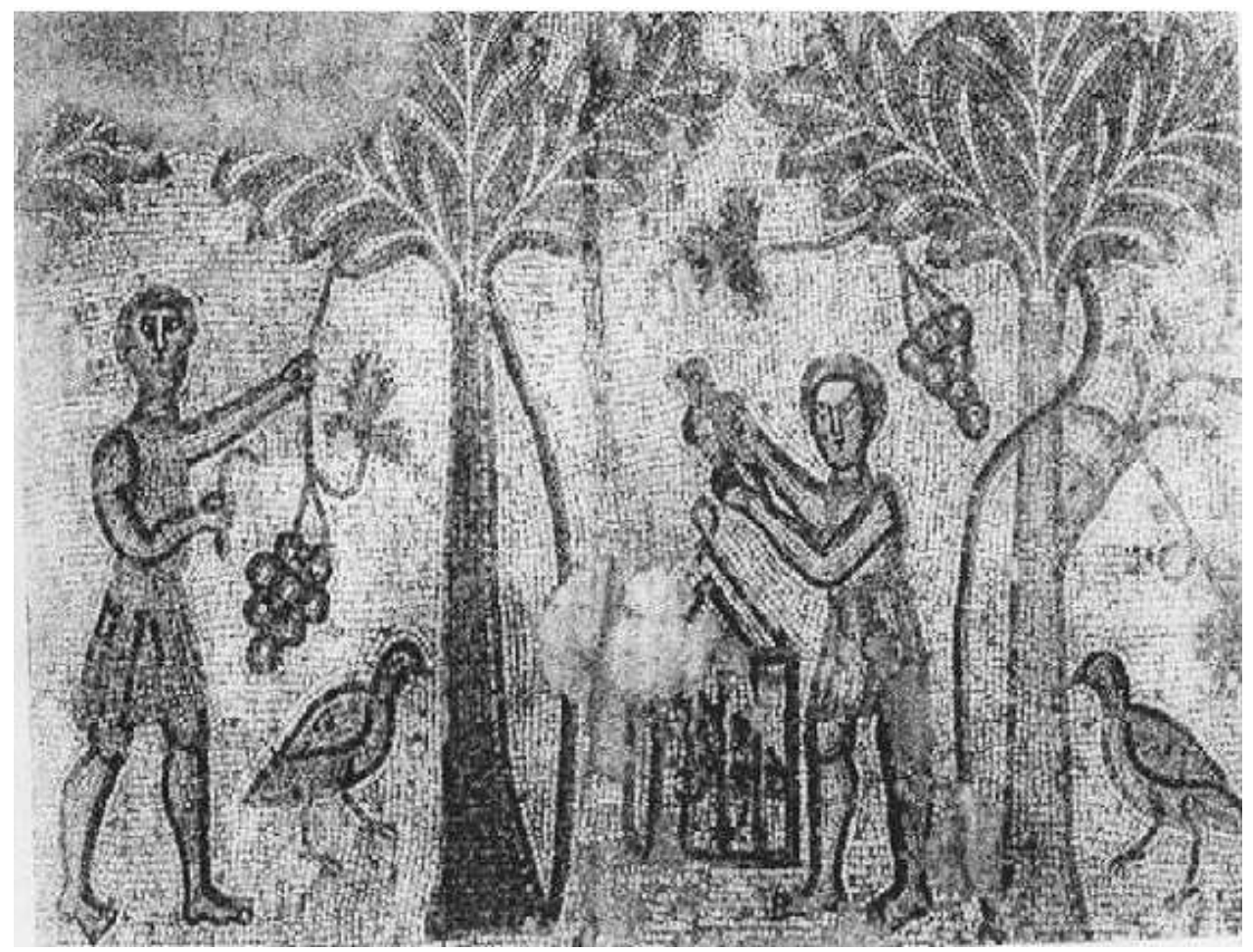

\section{Chrome on trees - Roman mosaic ${ }^{(12)(13)}$}

As the Romanian policy in Africa was essentially based on land- use as an indispensable economic base for Rome ${ }^{(14)}$, the Roman had to enact laws and put in place all legislation that would provide the legal framework for such exploitation on one hand and facilitate exploitation processes of the land and to recruit all its energy to serve Roman interests on the other hand. The first legal step was the expropriation of land and redistribution of Africa followed by a series of laws and legislation that paved the way for the widespread exploitation of African land to meet increased consumption and orientation of

\footnotetext{
${ }^{(12)}$ Brun J.P., Le vin et l'huile dans la méditerranée antique, Viticulture, oléiculteure et proceeds de fabrication édit. Errance, Paris, 2003, p. 37.

${ }^{(14)}$ Picard, Ch, le Civilisation, op. cit., p. 94
} 
agricultural policy according to the requirements of that consumption ${ }^{(15)}$.

\section{Agricultural legislation and legalization of land use:}

In accordance with Roman legislation, African lands were divided into groups, headed by the Fundi Populi Romani, after the dispossession of land. These lands were distributed to the aristocratic centurion class, who leased the lands to small farmers to cultivate them. In the imperial era, most of these lands became part of the Emperor's property. Then the land was owned by the Roman Emperor Patriomonium Principis, which is a private property and tax-exempt. Finally, there are the lands of the Loca Fiscalia, which include the rest of the public land and were often the least fertile. They have not been allocated to the Emperor nor to aristocratic class and therefore distributed to the people to exploit them in exchange for paying taxes, for this land was not recognized in the ownership of Roman law and it was possibly confiscated and evict tenants at any time ${ }^{(16)}$.

During the republican era Agrariae Leges was issued to regulate the cultivation, exploitation and to print these lands solid economic stamp. The laws created large productive units, including Latifundia and Salti. These units were distributed to the centurion class, imperial family and aristocratic local society in the states, which included the Roman and non-Roman that granted the privileges of Roman citizenship. Latifondia was a fundus or a number of Fundi, Villae or rural houses, of the gentlemen and relied on the rental of the people of the country with low wages or through forced labor. While Saltos were rugged mountainous terrain and porous land, they were difficult

\footnotetext{
${ }^{(15)}$ Hugoniot, Ch., op. cit., pp. 23-24.

${ }^{(16)}$ Picard, Ch. La Civilisation, op. cit., pp. 61-62.
} 
to exploit, but in the end Latifondia and Saltos were public property of the state, and they formed the Doman system ${ }^{(17)}$.

On the other hand, the legal legislation considered the Latifodnia within the territory of the city in Territorio and it was within the property of the emperor and in this case exempt from taxes. Latifondia was also obliged to pay its taxes, while Saltos was outside the territory of the city, outside the real estate of the cities and away from the population of the rural and urban areas. Saltos, as ltifondia, was exempt from tax, other than real estate tax, from which he is obliged to pay the known taxes ${ }^{(18)}$.

As for agricultural legislation during the imperial age, these laws were necessitated by the continuous Roman need to increase production, meet the needs of consumers, regulate the relationship between landlords, peasants and tenants, and determine the amount of taxes and collection methods. The legislation of the imperial era concerned the exploitation of nonfertile and neglected lands in order to increase the production of African lands without prejudice to the wheat crop, which occupied most of the fertile land ${ }^{(19)}$.

Agricultural legislation was based on two basic laws, the Mancianaa Act and the Hadrian Act of the first and second centuries, and their laws were merely supplementary or interpretative laws for some of their provisions.

\section{[1] The Law of Mancianaa:}

Is a law enacted to regulate the economic relations between landowners and their managers. The most important of these is

\footnotetext{
${ }^{(17)}$ Carcopino, J., Colonat Partiaire, in MEFR. XXVI, 1906, pp. 364ff; Saglio, E. et Autres, Dictionnaire des antiquités grecques et romaines, DAGR, Hachette, Paris, 1873-1919, p. 958.

(18) Chastagnol, A., La Legislation des biens des Villes au IVe Siecle á la Lumiere d'une Inscription d'Ephése, Attidell, Accad Romanistica Costantiniana 6 convegno intern, Perouse 1986, pp. 79-85.

(19) Cheniti, Muhammad al-Bashir, op. Cit., P. 83.
} 
the granting of property rights to those who rehabilitate arid or desolate lands that have been neglected without cultivation and are intended to encourage farmers to reclaim land that is not fertile, whether these lands were general or private Imperial Doman $^{(20)}$.

This law was attributed to an unknown person named Manciana who is likely to be a special emissary of one of the Flavian family emperors (69-96AD). He may have been a public official or a consular judge who takes upon oneself organizing economic relations in Africa; his work resulted in the promulgation of this law ${ }^{(21)}$. That sparked controversy among researchers on the date of its issuance and the personality of who issued it and we do not know the exact time in which this law was issued, but likely to be older than the law of Hadrian, and may date back to the first century $\mathrm{AD}$, which came into force since the reign of Emperor Vespasian (69-79AD). ${ }^{(22)}$

However, what is important to us from this law is that it left great marks on agriculture and continued until the end of the Empire or at least until the fifth century AD, and although the provisions of this law are not fully discovered, the archaeological texts discovered in Africa have pointed to a number of Items ${ }^{(23)}$.

The law of Manciana provides for the right to cultivate the land of culture's right in accordance with the provisions of the law and thus grant the right to all those who wish to work in agriculture, provided that the landowners are given their obligations. Then beneficiaries of the land have to grant the

${ }^{(20)}$ Peuras, J. La potestas occupandi dans l'Afrique Romaine in: DHA vol. 25, 1999, p. 133; Picard, Ch, Le Civilisation, op. cit., p. 63; Cuq, E., le colonat partiaire dans l'Afrique Romaine d'apres l'Inscription de Henchir Mettiche in: CRAI, No. 11, 1901, p. 143.

${ }^{(21)}$ Rostovsz, Michael, The History of the Romanian Social and Economic Empire, Vol. 1, Translated by Zaki Ali and Muhammad Salim Salem, The Egyptian Renaissance Library, Cairo, 1957, p. 434.

${ }^{(22)}$ Cuq, E., op. cit., pp. 143-144; Peuras, J. op. cit., p. 134; Hugoniot, Ch., op. cit., pp. $103-$ 104.

${ }^{(23)}$ Picard, Ch., et Rouge, op. cit., p. 211. 
owners all the crops as prizes. The amount obtained by owners is often one third of wheat production, one-third of barley production, one-third of the wine produced from the vineyards, and one-third of the olive oil extracted after harvest ${ }^{(24)}$.

The law of Manciana encouraged the cultivation of olives and vineyards in particular because of the increasing importance of oil and wine in Rome and Italy, so farmers were granted the right to use the reclaimed land and gave farmers the right to inherit the land as long as they continued to pay their obligations to landowners ${ }^{(25)}$.

\section{The Law of Hadrian:}

When the Emperor Hadrian (117-138AD) visited an African state, he witnessed the neglect inflicted on African lands and the deteriorating conditions of the peasants. He enacted a law on agrarian reform and the organization of lands that did not plant and de-cultivate lands. The purpose of this law was to link the farmers to the land and achieve economic stability through granting land-owning farmers the right lay hands or possessors, which is a legal right conferring the right of agriculture and usufruct and the right to inherit the land on condition of continuing to work and pay their obligations to owners of these lands ${ }^{(26)}$.

Thus, Hadrian's plan was to revive and supplement the provisions of the old Manciana Act. Hadrian wanted to achieve the same objectives as Manciana, which codifies the expansion of non-fertile land reclamation, and in some of its articles, farmers are entitled to use the lands of the Emperor and are also entitled to bequeath to their children in case of their cultivation, attention and reclamation. The landlords will lease this land to the farmers for one-third of the production paid by the farmers to the owners

\footnotetext{
(24) Ibid, pp. 212-213.

(25) Alberteni, T., Actes de l'epoque vandal, Pairs, 1952, pp. 108-109.

(26) Ostoftzev, Michael, op. Cit., Pp. 434-435.
} 
after harvesting the crops. The evil of the first years of fruiting and after payment is made, unlike olive farmers exempted for a period of seven years of repayment of production owners in the case of the cultivation fruit trees ${ }^{(27)}$.

One of the most important provisions of this law is to allow residents outside the Fondus to own the uncultivated lands that they worked on reclamation within the Vendors in return for paying the production premiums to the Fondus ' agents or owners one third of the production of wheat, beans or barley and five wines and oil. Its noteworthy, that this ratio of than one-third in the law of Mancianaa is lessend to the fifth in Hadrian's law and this is a victory for farmers.

Hadrian's law is distinguished by its ability to facilitate work in the Imperial Dumans and at the same time regulate agriculture and labor in all of Africa. Some believe that this law is related to the administration of the whole empire because it is flexible and suitable for various places and different types of property ${ }^{(28)}$.

\section{Archaeological texts and the most important legislative items:}

Archaeologists revealed the discovery of a collection of archaeological texts during the excavation in several locations in Africa and these texts are legal decrees in the form of inscriptions written on a stone monument and each decree related to the organization of a unit of production, whether an Imperial or Doman and most of them were based on the legal decrees Manciana and Hadrian relating to the development of agriculture and determining the relationship between tenants and owners ${ }^{(29)}$.

\footnotetext{
${ }^{(27)}$ Carton, Dr., La Lex Hardiana et son commentaire par le procurateur Partruchus, revue archeologique Tom. 21, Mars-Avril 1892, pp. 21-26.

${ }^{(28)}$ Carton, Dr., op. cit., p. 39; Saumagne, Ch., Inscriptions de Jean ez Zaytouna, in: CRAI 81, no. 4, 1937, p. 300.

${ }^{(29)}$ Le Bohec, Hisoire de l'Afrique Romaine 146 avat J.C. 439 Aprés J. C., Paris, 2005k, p. 138.
} 


\section{Text of Ain Jammela :}

This text is the most important legislative text due to the clarity of Latin inscriptions on it. This text dates back to 1906, which was discovered in Wadi Khallad near the Ain Jammela roundabout. This is a petition submitted by farmers at the Nironianos asking for official permission to cultivate uncultivated lands and marshes. The inscription on a signature stating that the petition submitted to them was accepted and allowed to be reclaimed according to Hadrian's law, which permitted this ${ }^{(30)}$.

\section{Ain Jammela's Inscriptions ${ }^{(31)}$}

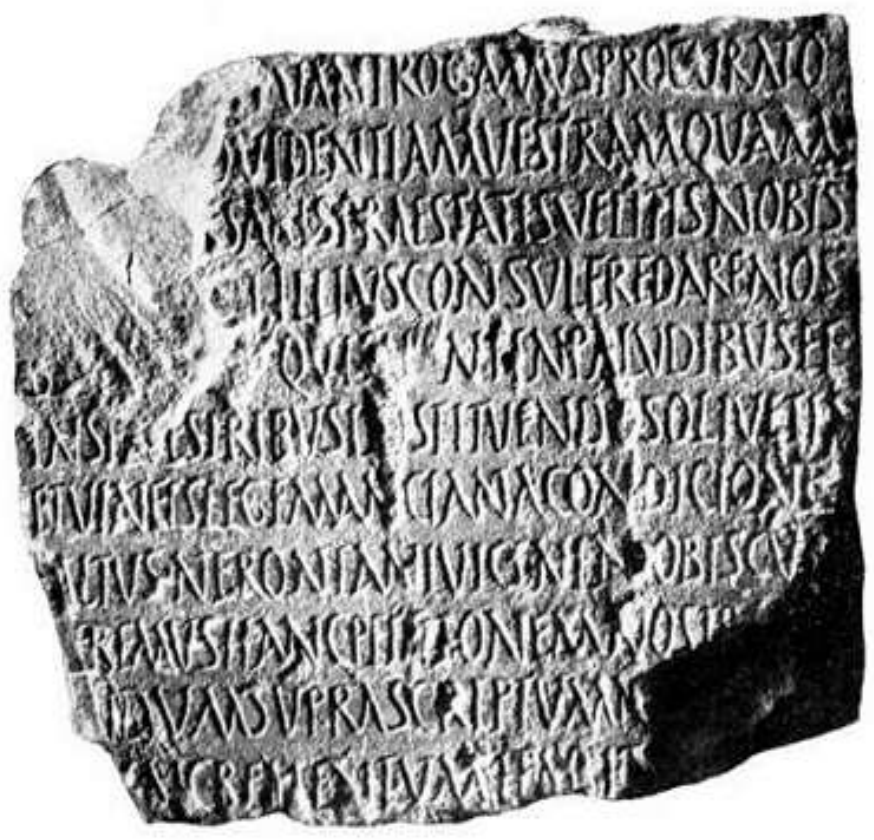

(30) Carcopino. J., L'inscription de Ain Djemala, Melange d'archeologie et d'histoire, Pairs, 1906, pp. 540-541.

(31) Carcopino J., L'inscription de Ain-Djemala, Mélanges d'archéologie et d'histoire, Paris, 1906. 
I.

\begin{tabular}{|c|c|}
\hline 2 & 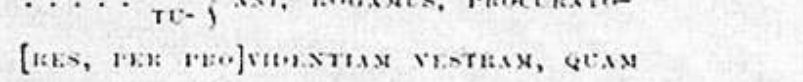 \\
\hline 3 & 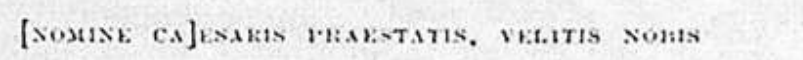 \\
\hline 4 & 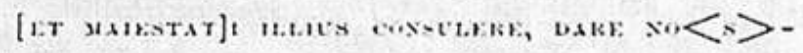 \\
\hline 5 & 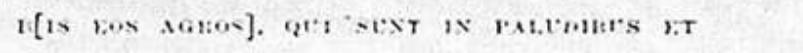 \\
\hline G & 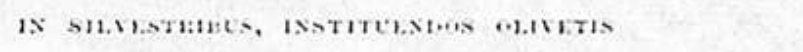 \\
\hline$\tau$ & 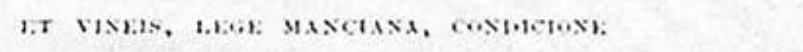 \\
\hline$s$ & 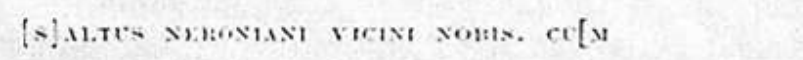 \\
\hline ! & 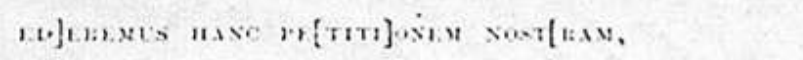 \\
\hline 10 & 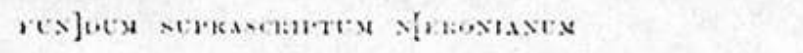 \\
\hline 11 & 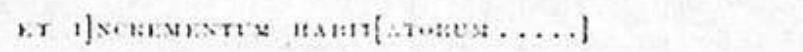 \\
\hline
\end{tabular}

(... We ask you, agents, in the name of the Emperor Caesar, based on the wisdom we have to implement which benefits us. His Majesty has decided to give us the swamps to be planted with olive trees and vineyards according to the law of Manciana and according to the conditions of our neighboring Saltos Neronianos.

By submitting this petition we believe that we are thinking of the Neronian estate and an increase in the population ...)

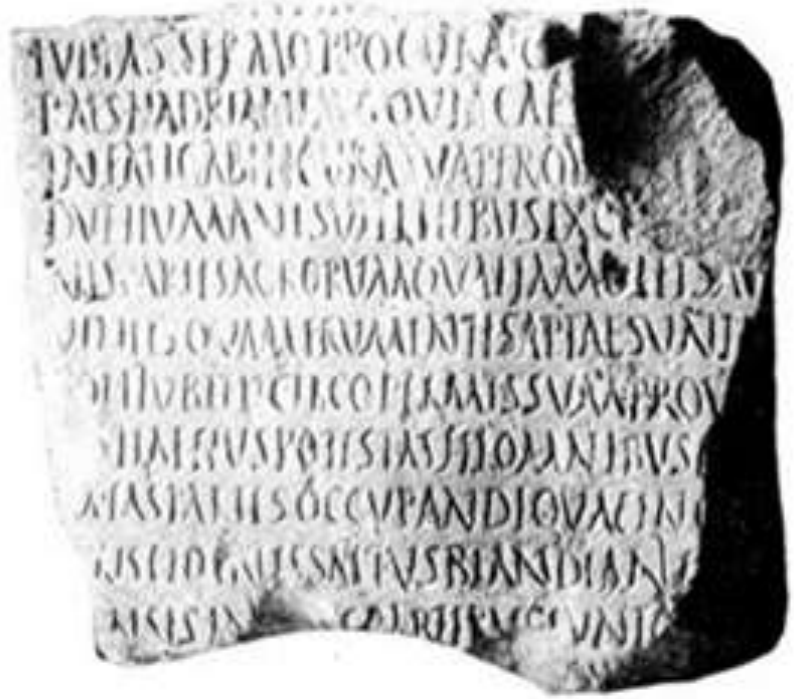


II.

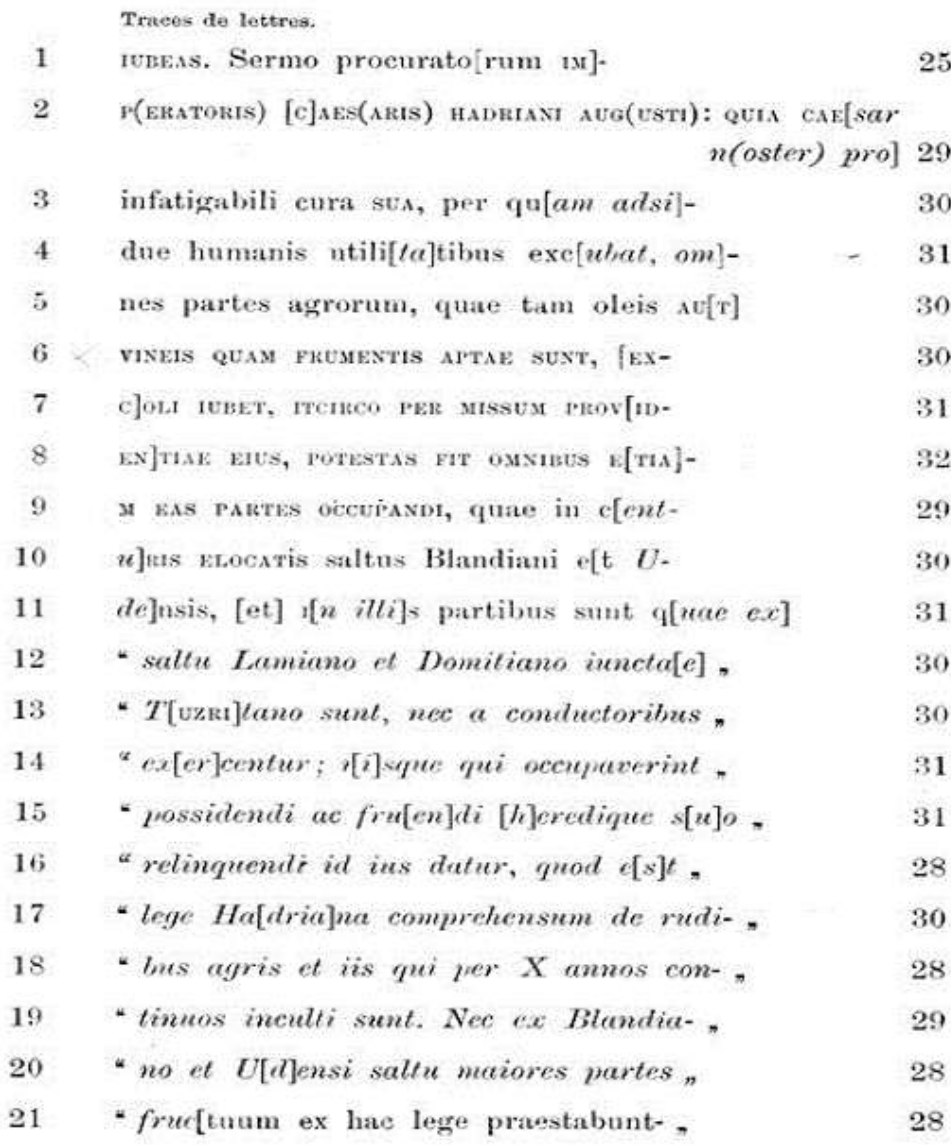

The second facade

(Based on the command of our Caesar, who seeks to guarantee the eternal happiness of mankind, orders the exploitation of all parts of the private lands suitable for the cultivation of olives, vineyards and grain, and therefore, in the divine providence, the power granted the right to everyone to use the land in the division of land survey and lease of the lands of Blandianus and Judensis, which was annexed to the ownership of Tozarianos, which was not exploited by the farmers and the right of those who work to own, use and then bequeathed and this is the right determined by the law of Hadriana on the land of the 
fallow and uncultivated land for successive ten years, and on the land of Blandianos and Judensis to deliver under this item part of the production is higher than the part they receive elsewhere.)

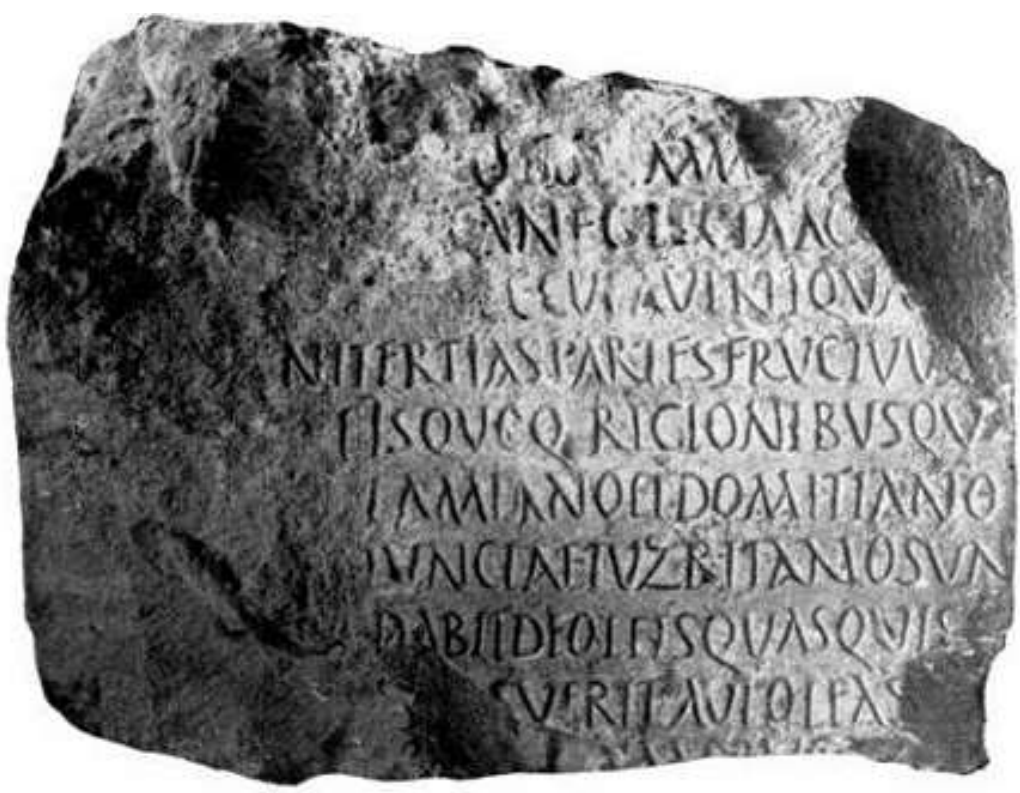


III.

1 ur $q] 0 \wedge[m$ aliund $]$ o[b lege $]$ s s[aneianam; (?) 29

2 set si quis lo]ca Neglecta a co[ndu- 27

3 ctoribus] occupaverit, QUa[e da- 25

4 ri sole]nt, tertias partes fructun $[\mathrm{m} \quad 29$

5 dalit; de] EIs quoq(ue) reglosibus q0- 26

6 [ae ex] Lamiano et Domitiano 22

7 [saltu] iunctae Tuzmitano sunt 24

8 [tantumdem] Daвнт. De oleis quas quir [q(ne) 30

9 e possessoribu]s [po]suerit aut olens $[\mathrm{tr}-\quad 32$

10 is inseruerit] c[aptor]um fruct[uum 28

11 "nulla pars] decem proximis amis exige- , 32

12 " $t[\mathrm{rer}]$; set nec de pomis septem annis jwo- . 30

13 "ximis; nec alia poma in divisionem umq-, 31

14 " uam cadent, $q u[a] m$ quae venilunt a posses- , $\quad 32$

15 "soribus. Quas partes aridas fructum" 31

16 "quisq(ue) debebit dare eas pr[o] rimo quinq- . 31

17 "uennio ei dabit in cuirs conductione. 31

18 - agr(os) occupaverit; post it tempus rationi .. 33

\section{The third facade}

(...According to the law of Mancianaaa, the workers in the neglected areas should be given the usual part which is a third of the production.

As for the cultivation of olives or the vaccination of wild olives, the owner is exempted from taxes for 10 years and seven years for other fruit trees, while fruit is not taxed except in the case of owners to sell them, but the grain pays taxes in the first five years to the owner of the land and five other years to the departement of the land...) 


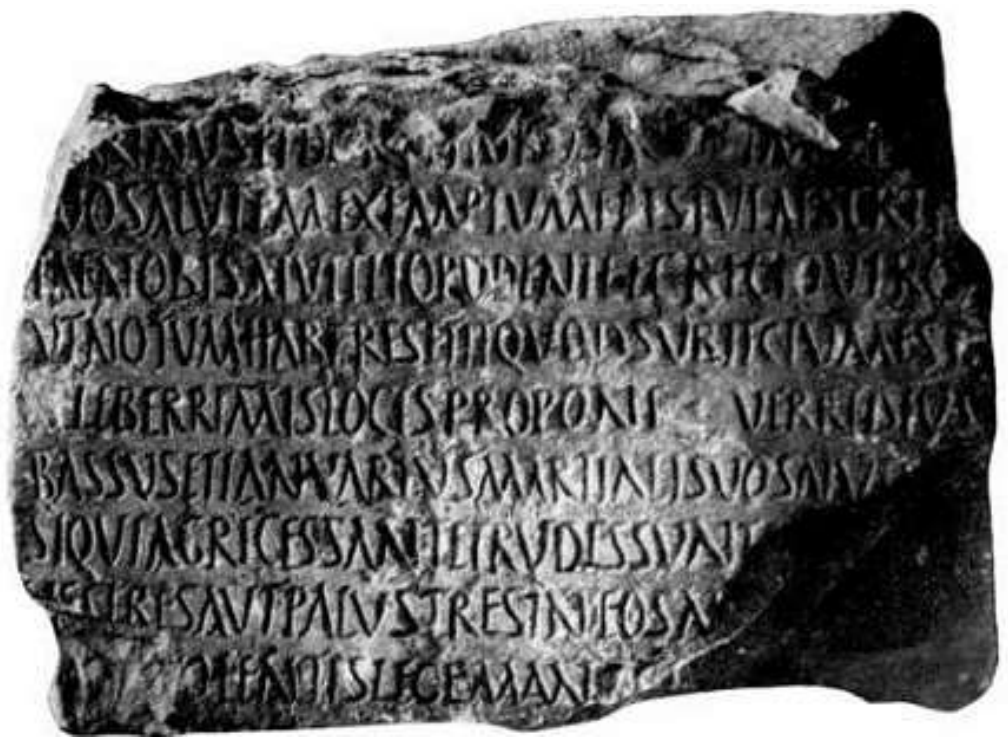

IV.

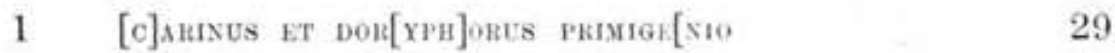

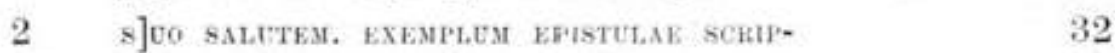

3 TAE NOBIS A TUTHLIO PUDENTE, EGKEGIO VIKO, 34

4 UT NOTUM HABEKE, ET IT QQUOD SUIECTUM ENT

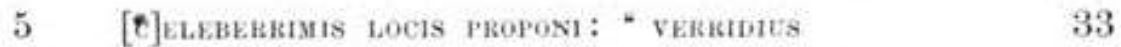

6 BAsSUS ET INNUARIUS MAHTLAL RUO SALUT[EM]: 35

7 SI QUI AGRI CKSANT ET RUDES SUNT; [SI QUI SH-] 35

8 NESTKES AUT PALUSTKES IN EO SALT[UUM TRA- 33

9 CTU, v]OLENTIS LEge MaNein[Na.....,

Traces de lettres.

\section{The fourth facade}

(.... if there is neglected land which is the uncultivated land and if it is found in this area of the farm whether it was jungle or marshes it can be restored according to the law of Mancianaa

[2] The text of Henchir Mettich,: which was found in Wadi Medjerda in Tunis in 1896 by Lieutenant Boulane, belongs to a fendi known as Mappalia Siga, a decree inspired by the law of Mancianaaa and includes Parts of its articles and chronicle some 
of the era of Trajan (98-117 AD) while some return to the end of the second century and specifically in the era of Emperor Septemius Severus (193-211 AD)

Through this text, some of the provisions of the Mancianaa Act and the Hadrian Act recognized the right of farmers outside the Villa Magna Variana lodge to acquire the land they could cultivate and reclaim after they were barren, with the obligation to pay the quota to the owners of these lands. The text of Hansir Matish contains items related to exempt farmers who grow figs and vineyards from paying taxes only after five years of agriculture and ten years of olive cultivation ${ }^{(32)}$.

2. The text of Ain Wasel: This is known historically as the decree of Sermo Procuratourm, and was revealed by the military doctor Carton around 1891 near the spring of water named Ain Wasel in Tunisia, an inscription on three stone monuments, and it provides The right of ownership and the system of payment of tax premiums

In his study, it became clear that it was a decree of Saltus Burunitanus, which included a chapter of the Hadrian law. This text often dates back to the era of Emperor Septemius Severus (193-211AD), which was issued by the agents of Septemius Severus in $210 \mathrm{AD}$ to reorganize agriculture according to Hadrian's law ${ }^{(33)}$.

Through the text of Ain Wasel, five imperial Salatos were identified in Wadi Medjerda in Tunisia ${ }^{(34)}$.

4. The text of Souk el Khamis: is dated to 174-223 AD during the Marcus Aurelius and Flacos Cornelianus, a decree regulating the Colon status of farmers who benefit from the land of others or

\footnotetext{
${ }^{(32)}$ Cognat, R., Inscription d'Henchir Mettich, CRAI, 41, No. 2, 1897, pp. 151-152.

${ }^{(33)}$ Mespoulet, M., L'inscription d'Ain Ouassel, Nouv, Revue Hist. De Droit francais, MarsAvril 1892, pp. 124ff; Carton, Dr., op. cit., p. 9.

(34) Aqud, Muhammad al-Arabi, op. Cit., P. 91.
} 
those who have acquired the right to reclaim uncultivated lands ${ }^{(35)}$.

5. The text of Janan al-Zaytouna: is very similar to the text of Ain Jammela, as it is a petition submitted by farmers to approve the reclamation of Uncultivated lands in arid lands and marshes based on the law of Mancianaa ${ }^{(36)}$.

6. Other archaeological texts have been uncovered in North Africa, including the text of Henchir Snobeur, which dates back to 1861. It concerns the right of Possessores.

7. Text of Henchir Zaytouna, dated between 202-205 AD.

8. In addition, there are the contracts known as the Tablets of Albertini, which are pieces of wood, not stone, found in 1928 with several documents representing the sale and purchase of the lands of a major property in the city of Tebessa, Algeria. Since it dates back to the reign of King Vandale Gentamund (484-496), they were known as valentine contracts, which indicates the continuation of the work of the Roman agricultural legislation derived from the laws of Mancianaa and Hadrian until the end of the fifth century $\mathrm{AD}^{(37)}$.

It is clear, in this sense that the policy of agricultural legislation and subsequent legal decrees and laws were based on linking the farmers to the land and urging them to take care of them either by granting them the right of ownership and use or inheritance, and using two-thirds of production and temporary exemption from taxes until the completion of reclamation. All benefit from agricultural expansion in favor of bridging Rome's need for food, olives, wine and other consumer $\operatorname{crops}^{(38)}$.

\footnotetext{
${ }^{(35)}$ Lacroix. F., L'Afrique Ancienne, Revue Afrique, vol. 14, 1870, p. 26.

(36) Saumagne. Ch., op. cit., pp. 295-296.

${ }^{(37)}$ Le Bohec, op. cit., p. 138; Albertini, E., Documents d'epoque Vandale de couverts en Algerie, CRAI, 72, No. 3, 1928, pp. 301-303.

${ }^{(38)}$ Carton. Dr., op. cit., p. 39.
} 
The Roman administration was aware of the importance of encouraging farmers and pushing them to expand in the field of agriculture and production. However, after these privileges granted to farmers did not neglect the aspects of owners or the general interest of the Roman economy where the legal and legislative provisions obliged farmers after having these privileges to work for six days free of charge every year, two days during tillage and two days during the harvest season and two days to get rid of the harmful herbs by planting. This is in addition to obliging outsiders to register their names for periodic patrols to protect production from any dangers, especially theft, looting or $\operatorname{arson}^{(39)}$.

\section{The Impact of agricultural legislation on the African general economy:}

\section{[1] Agrarian Reform:}

\section{(A) Agricultural expansion and land reclamation:}

Agricultural legislation has had an impact on the development of African agriculture in general. Archaeological texts indicate the orientation of Roman policy towards horizontal expansion in agriculture by maintaining the cultivation of wheat in fertile lands and turning to the cultivation of uncultivated lands suitable for the cultivation of olive trees and vineyards in order to produce oil and wine. The agricultural concessions provided by the legislation encourage farmers to apply for land reclamation according to the laws of the organization. Hence, the second century $\mathrm{AD}$ witnessed a great expansion in African agriculture $^{(40)}$.

Through this expansion, farmers have made some gains, including improving living conditions, social conditions, land use and inheritance, and a sense of socio-economic stability within

\footnotetext{
${ }^{(39)}$ Picard et rouge, op. cit., pp. 214-215; congat, R., op. cit., p. 153.

${ }^{(40)}$ Picard, Ch., l'civilisation, op. cit., p. 62.
} 
the framework of organized laws guaranteeing stability for all. Over time these laws have become firmly established in the management of the African economy ${ }^{(41)}$.

The policy of reclamation of the uncultivated lands was based on the cultivation of trees, especially olive trees and vineyards. Due to the importance of these trees in the oil and wine industry, the second century AD was known as the olive and vine centuries. The Roman aims were to expand these crops through the importance of oil and wine in Roman economic life to the extent that oil is one of the main sources of wealth and was a testament to Roman politics in Africa ${ }^{(42)}$.

Archaeological evidence indicates the importance of the olive tree in old economy, especially in the Mediterranean countries, where it is one of the most important exports of these countries. The oil extracted from it is very important in the field of food, which is used in cooking and food preparation as well as its importance in the perfume, lighting and health care industry. It was also an important commercial commodity that comes after the grain trade to profit farmers ${ }^{(43)}$.

The olive tree was old in North Africa and was found by the Roman there because African land was suitable for cultivation. The Carthaginians benefited greatly from the oil industry, which gained widespread fame for lighting and public baths because of its strong aroma ${ }^{(44)}$.

But the Roman administration was the cause of succeeding in increasing the productivity of this tree from the second century $\mathrm{AD}$ at the expense of the useless land, Roman administration was

\footnotetext{
${ }^{(41)}$ Aqoud, Muhammad al-Arabi, op. Cit., P. 83.

${ }^{(42)}$ Leveau, Ph., A propos de 'lhuile et de vin en Afrique Romaine ou pourqoui deromaniser l'archeologie des compagnes d'Afrique, Revue pallas tom. 68, 2005, p. 78.

${ }^{(43)}$ Precheur Canonge, La Vie Rurale en Afrique Romaine, d'apres les Mosaiques, Paris sans date, p. 48; Boissier, G., L'afrique Romaine, Hachette, Paris, 1907, p. 147.

(44) Juvenale, Satires, V, 86, 91.
} 
able to exploit these lands for the benefit of the African economy in general and for the benefit of the Roman economy in $\operatorname{particular}^{(45)}$.

The Roman interest in the expansion of olive cultivation was due to several factors, including the decline of olive cultivation in Italy, which was the most important source of oil in Rome. Africa has become a quick alternative to make up for the needs of olive and highlighted the importance of olive peak during the rule of the Severan family (193-235 AD). Although chaos occurred during the third century, however, olive cultivation continued to expand southward until the outskirts of the desert, leading to the transformation of desert and pastoral lands into productive lands. As a result, the Bedouins have transformed into stability and disbanded their movements, which were very influential in agriculture ${ }^{(46)}$.

The cultivation of the vineyards was also ancient in Africa, and at the beginning of the Roman presence in Africa, the Roman administration was not interested in protecting the Italian farmers from the competition of the African vineyards. The African coin shows the viability of viticulture in Africa before the Roman era. Africa comes after Crete in terms of quality ${ }^{(47)}$.

With the deterioration of Italian agriculture, the Roman took great interest in planting vineyards alongside olive trees due to the increasing importance of economic and commercial vineyards, so that African wine became one of the most important commodities exported to Italy and the Mediterranean countries $^{(48)}$.

\footnotetext{
${ }^{(45)}$ Camps, G., Aux Origines de la Berberie, Massinissa ou les Debuts de l'Histoire, Libyca, 1962, pp. 86-87.

(46) Aqoun, Muhammad al-Arabi, previous reference, pp. 101-103.

${ }^{(47)}$ Pline, XVIII, 188.

${ }^{(48)}$ Billiard, R., la Vigne dans l'antiquite, Lyon, 1913, pp. 15-16.
} 
In the third century $\mathrm{AD}$, the increase in the population and the spread of Christianity led to an increase in the demand for wine, which was an indispensable holy drink. The Roman administration expanded vineyards to extract wine from it until wine became one of the main pillars of the Roman economy ${ }^{(49)}$.

\section{(B) Evolution of the irrigation system:}

While the African coasts benefited from the rainwater, the southern regions suffered from drought and lack of rain, which exposed the cultivation of grain and tree planting at risk. The Roman had to search for an alternative through the establishment of an integrated irrigation system. The evolution of the irrigation system went hand in hand with increased attention to agricultural expansion and reclamation so the Roman did not leave the water spring without watering the land from it.

Thus, the agricultural legislation for the expansion of the cultivation of the uncultivated lands with vineyards and olives prompted the Roman administration to provide the means of irrigation for the success of this policy. The Roman worked on the construction of dams, reservoirs and wells where the dams collect and store rainwater. The idea of the reservoirs is to provide a series of waterways to store rainwater and floods and to transfer them to the reservoirs for preservation, while archaeological studies have revealed a network of wells drilled at deep depths up to 59 meters ${ }^{(50)}$.

In addition, the Roman established numerous transport channels that transport water to agricultural land after supplying the cities with drinking water. the Roman also set up reservoirs that serve as reservoirs for the reception of water from water sources ${ }^{(51)}$.

\footnotetext{
${ }^{(49)}$ Pline, V, 3-4, XII, 133; Gsell. S, op. cit., p. 9.

${ }^{(50)}$ Gaukler, p. Enquête sur les les installations hydrouliques Romaines en Tunisie, Tunis, 1897-1912, pp. 205-206.

${ }^{(51)}$ Shinti, Muhammad al-Bashir, op. Cit., Pp. 109-110.
} 
The archaeological texts indicate the attention of agricultural legislation to regulate and develop irrigation to promote agricultural expansion. The most important documents related to irrigation are the Lamasba document, which is a legislative text engraved on a stone slab bearing the names of the farmers benefiting from the land and the number of plots owned by each farmer and the number of irrigation hours For each beneficiary to benefit from, as well as to identify the days and months in which he is authorized to irrigate ${ }^{(52)}$.

\section{2] Industry growth:}

Despite the Roman view of Africa as a predominantly agricultural state, the agricultural legislation that accelerated the agricultural growth has also contributed to the growth of some industries related to agriculture. The oil industry, which is associated with the expansion of olive trees, Africa is evidence of the development of this industry during the Roman era for its use in food and health purposes as mentioned above ${ }^{(53)}$.

The oil industry has developed widely in Africa, which has led to an increase in the number of oil presses during the Roman era. Archaeologists have uncovered many major industrial works such as the Khirbat Yaqub quarry near Setif, as well as the presence of contemporary cities such as the mill of Madorush and Hammam Bou Hanifia. There was no house without a small home-use Juicer ${ }^{(54)}$.

${ }^{(52)}$ Decret. F., Et Fanter, op. cit., p. 218.

(53) Aqoun, Muhammad al-Arabi, op. Cit., Pp. 124-125.

${ }^{(54)}$ Camps-Fabrer, H., op. cit., pp. 57-58. 


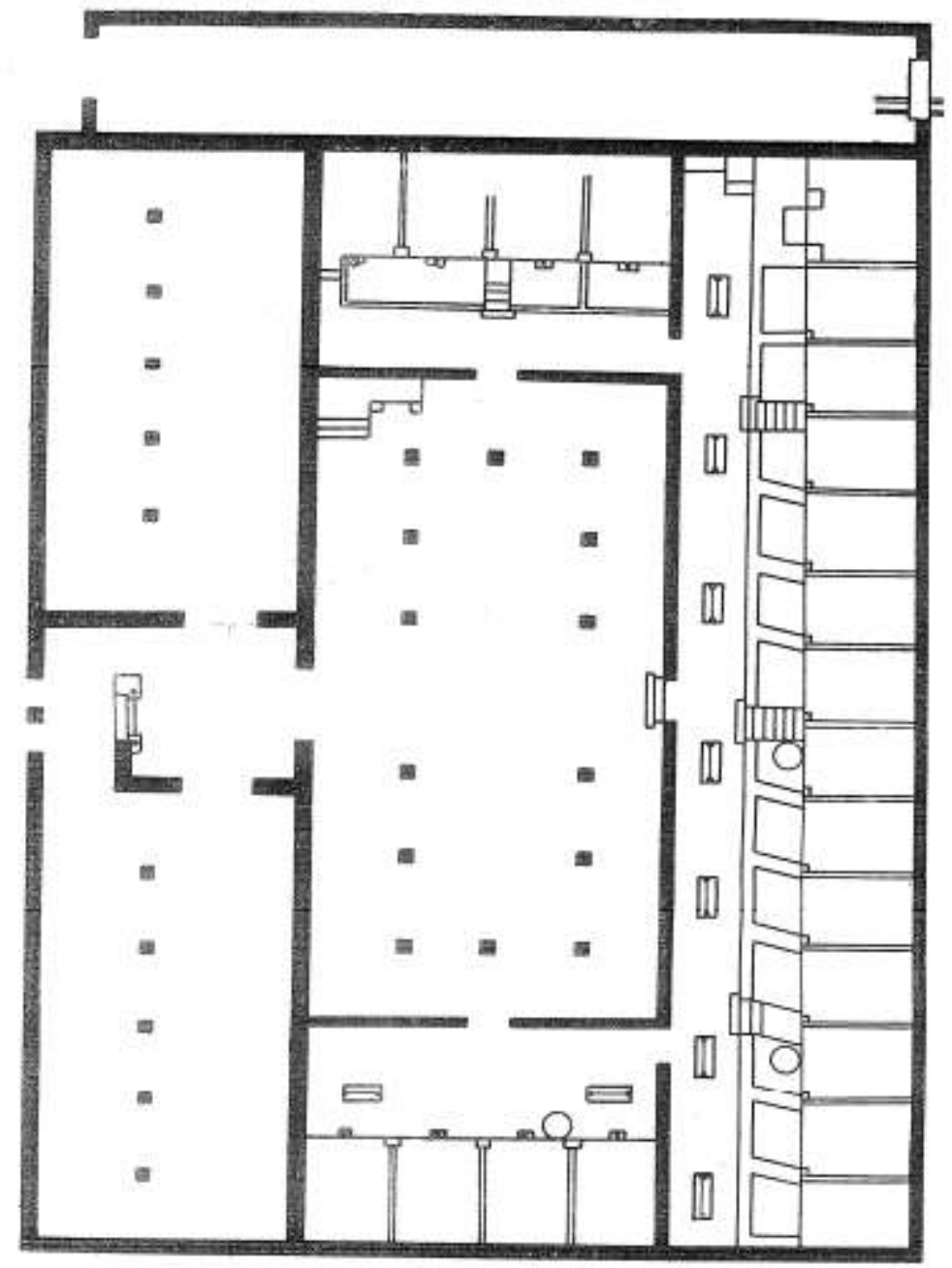

Khirbet Yaqoub Oil Press ${ }^{(55)}$ - Graphic

${ }^{(55)}$ Menuier (J), L'huilerie romaine de Kherbet-Agoub (Périgotiville, Bulletin de lasociété Historique et géographique de la region de Sétif, tome. II, (1941), p. 145. 


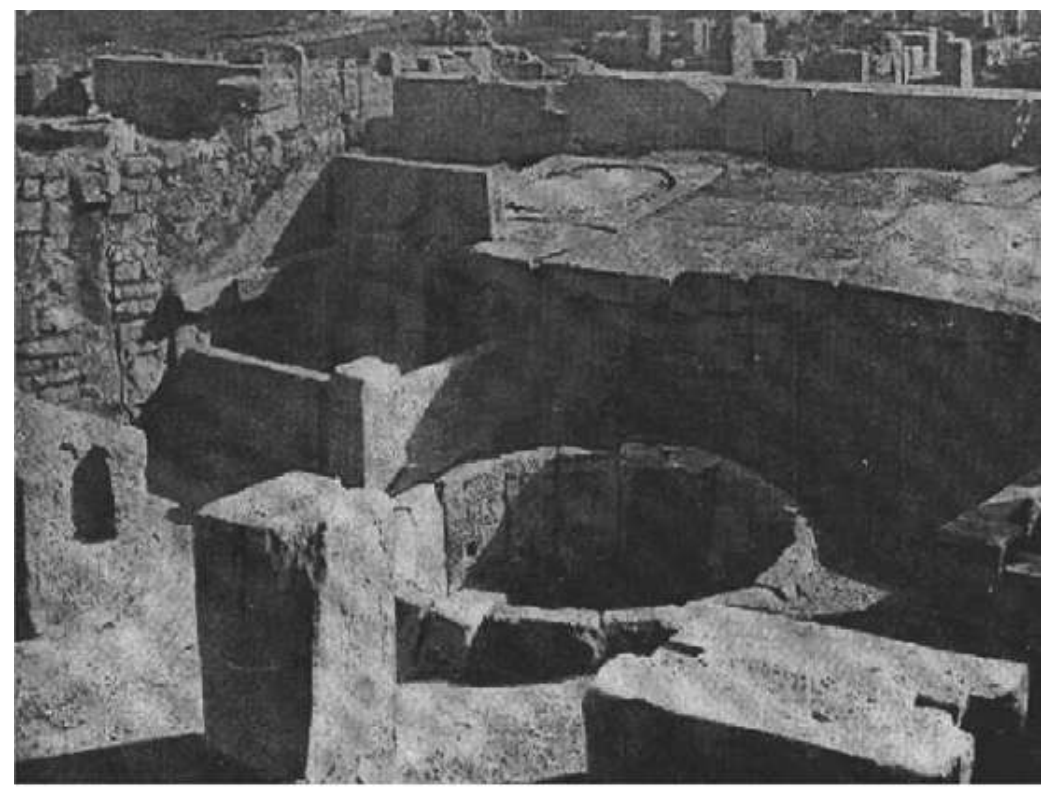

Maduroch Oil Production mill ${ }^{(56)}$

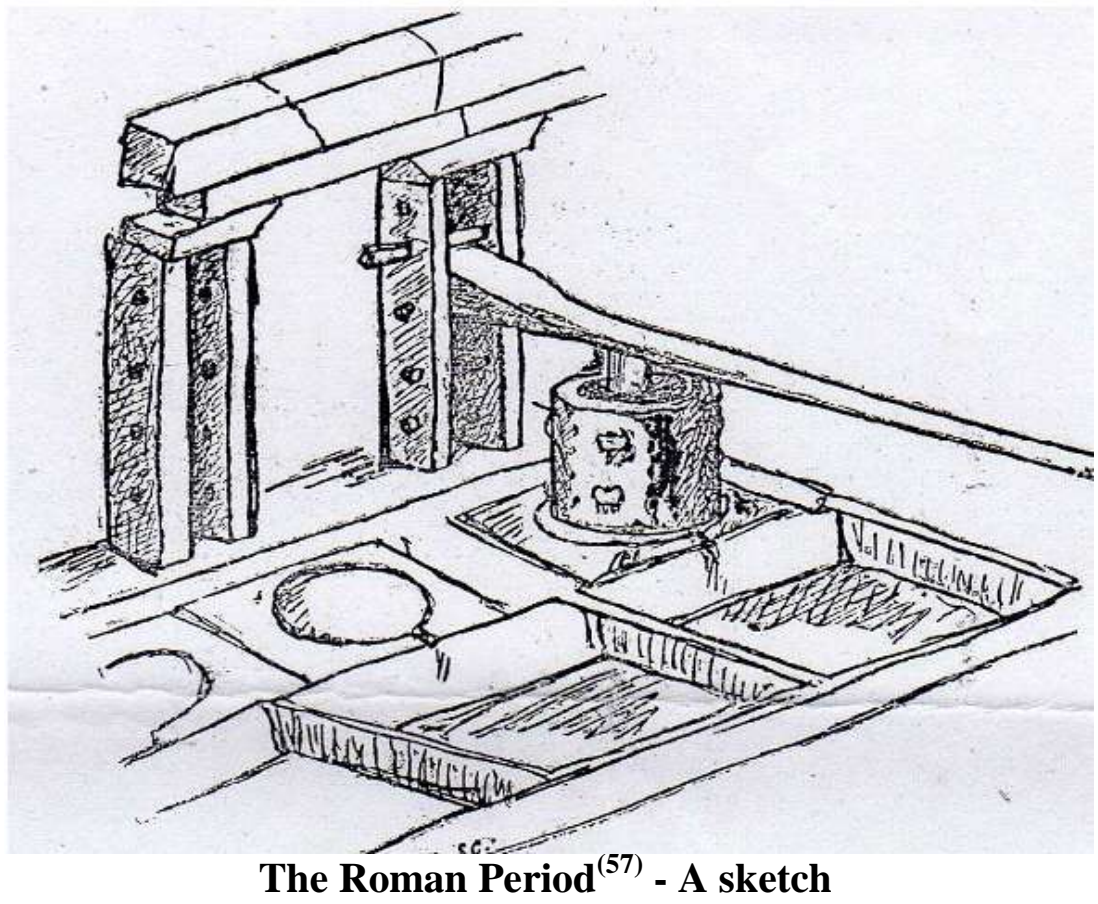

(56) Marcel (Ch), Essaie de restitusion d'un moulin de l'époque Romaine à madaure (Constantine), Alger, 1930, p. 260.

(57) Marcel (Ch), Essaie de restitusion d'un moulin de l'époque Romaine à madaure (Constantine), Alger, 1930, p. 260. 
The expansion of viticulture has also led to growth in the wine industry, especially after the deterioration of this industry in Italy. The wineries were very closely associated with the oils industry. It was believed that oil and wine were the most important African products in the Roman era. However, the discovery of wine making tools in Africa was less than finding contemporary oils because of the lightness and simplicity of these tools ${ }^{(58)}$.

The oil and liquor industry has been associated with parallel industries such as the storage Jars industry for use in storing these products and initially making African-style Jars. These Italian models of Jars industry in the second century reflected African culture. An African model of Jars manufacturing was found above the tectachcio height and was intended for oil storage and another wine storage model $^{(59)}$.

\section{3] Road construction:}

Land surveying, which was associated with agricultural expansion, led to the establishment of roads, which later proved to be important for the expansion of the south and the penetration and control the Numidian depth. The construction of the roads was initially for military purposes but soon achieved great economic objectives, resulting in the activity of trade movement ${ }^{(60)}$.

Since the era of the Flavius family, there has been increased interest in the expansion of a major road network in the State of Africa, some of which have been for oil and some for wheat or both $^{(61)}$.

\footnotetext{
${ }^{(58)}$ Adam. J. La Construction Romaine 3ed., grand manuels Picard. S.D., p. 341.

${ }^{(59)}$ Slim, L et Bonifay. M., L'Usine de Salasion de Neapolis, Premiers resultats des Fouilles 1995-1998, Africa XVII, 1999, pp. 153 ff.

${ }^{(60)}$ Carcopino, J. Le Marco antique, ed., Gallimard, Paris, 1948, p. 192.

${ }^{(61)}$ Vel, A., Quelques inscriptions, RSAC, vol. 43, 1909, p. 261.
} 
Herein, the establishment of the road network, in addition to military purposes, was aimed at economic exploitation in facilitating and transporting African products such as oil, cereals and wine.

\section{[4] Trade movement:}

As agricultural legislation has been an engine for land reclamation, it has also contributed to the growth of commercial activity inside and outside, where grain, oil and wine markets emerged in the cities of Africa, Toka and Toporsk were the most important oil markets. In terms of foreign trade, wheat and oil were the most important African exports. The Roman relied on a number of ship owners, whether Roman or African, to take over permanent transfers, especially wheat, oil and wine to fulfill Rome's need for these commodities, as well as for the rest of the African goods, to satisfy the public ${ }^{(62)}$.

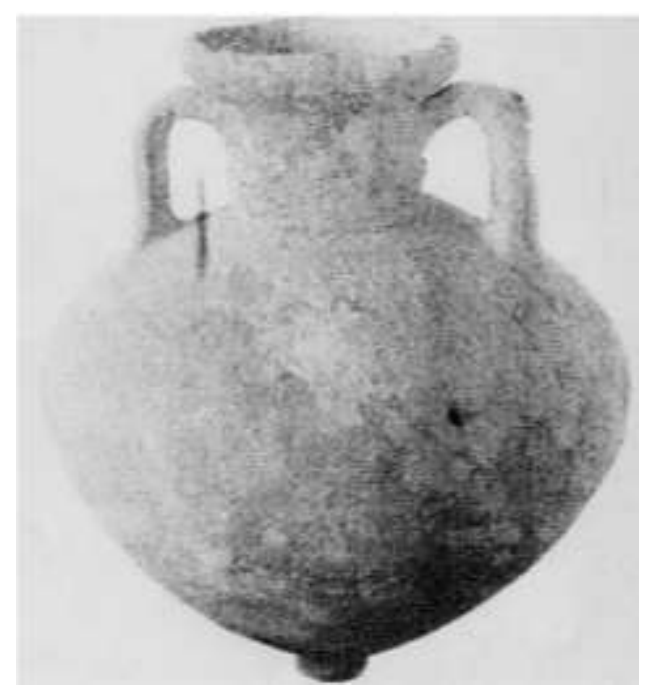

A wine Jar $^{(63)}$

A large stack of African oil potter (jars) above the Monte Testcchio height near Rome was found and this heap was

${ }^{(62)}$ Lecocq. A., Le commerce de l'Afrique Romaine BSGO, Tom. XII, 1932, pp. 340-342.
${ }^{(63)}$ Burn, J.P., Le Vin et l'huile dans la méditerranée antique, p. 88. 
formed over time and successively African oil (yield) tax to Rome, which shows the boom in the African oil industry and trade, and until the end of the first century Africa was supplying Rome with the wheat it needed for eight months while Rome relied on Egypt in the other four months. African traders played a prominent role in supplying Rome with wheat since the age of Emperor Trajan so that the ports of Africa have been directly linked to the port of Ossetia in Italy and the export of wheat and oil has not stopped to Rome at any time.

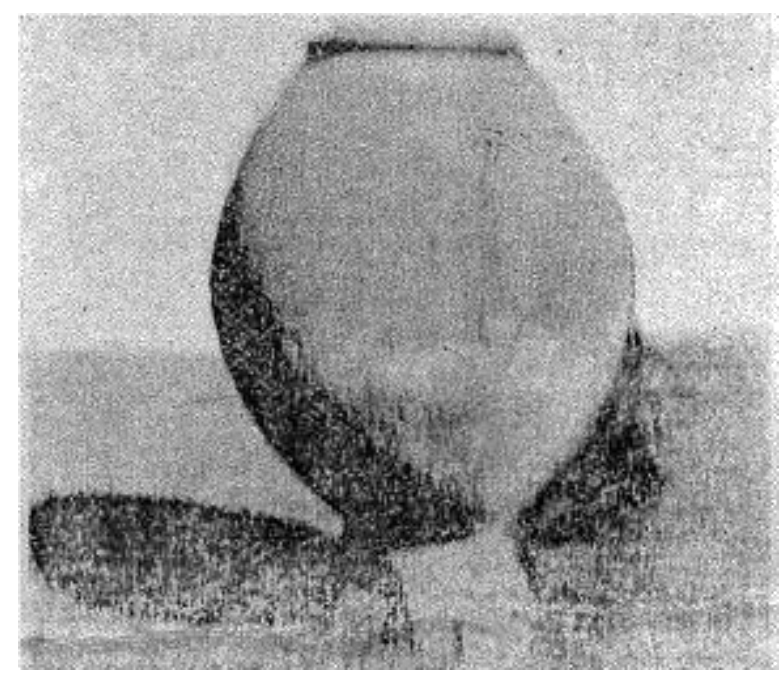

Jar to save oil from Tipasa ${ }^{(64)}$ - Roman era

\section{Conclusion and research results:}

It is clear from what was presented in the research that the status of Africa for the Roman economy has only grown as of the second century A.D. until the end of the Roman rule of Africa. The land-use policy has evolved from simply cultivation of wheat in fertile land neglecting arid lands, to seeking exploiting these lands in olive and chromium cultivation according to the need of the Roman market and consumer.

${ }^{(64)}$ Trabut (Dr.) l'Olivier en l'Algerie-Alger 1900, p.85. 
Agricultural legislation has played a significant role in regulating African agriculture and has successfully directed the African economy into diverse areas, where the agricultural map has been developed through the exploitation of other lands, the expansion of the South and the non-sufficiency of the African coastline.

The archaeological texts found in Africa represent a valuable demonstration of the success of such agricultural legislation and the capacity of the Department to implement it, as many petitions for the reclamation of land restoration have been effectively discovered.

Agricultural legislation has had the greatest impact on the overall African economy, with agricultural expansion pushing the public production wheel towards irrigation development, the construction of roads to serve the Roman project, and the resulting growth in agro-based industries and the development of the trade movement.

While agricultural legislation was originally aimed only at Roman interests, it left its influence at a far-reaching level on the development and growth of economy and wealth of Africa, the emergence of major cities and industrial centers, agricultural legislation have contributed significantly to improving the situation of Africans and raising the social level and living for them.

The agricultural policy and associated legislation resulted in many public and private benefits, thus serving the Roman citizen in Rome and benefited immigrant Italian farmers to Rome and have given rise to the Africans themselves, and created to Roman and others living in Africa a life worthy of survival in this state, for Profit and investment However, it has not been able to dissolve the African character under the Roman model, and Africa has maintained itself and defended its character until the end of the Roman rule. 
Roman emperors during the study period

\begin{tabular}{|c|c|}
\hline Year of Rule The & The Name of Emperor \\
\hline $23 \mathrm{BC}-14 \mathrm{AD}$ & August \\
\hline 14-37 AD & Tiberius \\
\hline $37-41 \mathrm{AD}$ & Caligula \\
\hline $41-54 \mathrm{AD}$ & Claudius \\
\hline 54-69 AD & Nero \\
\hline 69-79 AD & Vespasian \\
\hline AD 79-81 & Titus \\
\hline AD 81-96 & Dumitianos \\
\hline AD 96-97 & Nerva \\
\hline AD 97-117 & Trajanus \\
\hline AD 117-138 & Hadrianos \\
\hline 138-161 AD & Antoninus Pius \\
\hline AD 161-180 & Marcos Orlius \\
\hline AD 176-180 & Commodus \\
\hline 193-211 AD & Septimius Severus \\
\hline AD 211-217 & Caracalla \\
\hline AD 217-218 & Macrinus \\
\hline AD 218-222 & Elagabalus \\
\hline AD 222-235 & Severus Alexander \\
\hline AD $235-238$ & Maximianus \\
\hline AD 238 & Gordian II I Gordian \\
\hline AD $238-244$ & Gordian III \\
\hline AD 244-249 & Philip I \\
\hline AD 249-251 & Decius \\
\hline AD 251-253 & Claudius \\
\hline AD 253-259 & Valerius \\
\hline AD 268-270 & Claudius II \\
\hline AD 270-275 & Aurelianus \\
\hline AD 282-284 & Carros \\
\hline AD 284-305 & Diocletian \\
\hline
\end{tabular}




\section{Sources and references of the study}

I : Literary Sources:

1. Juvenale, Satires, V, 86, 91.

2. Pline, V, 3-4;

XII, 133;

XVIII, 188.

II: Arabic and Arabized references:

1. Jamal, Mokhtar, The History of Africa, Volume II, John Afrik Publishing House, UNESCO, 1985.

2. Rostovsz, Michael, History of the Romanian Social and Economic Empire, C1, Translated by Zaki Ali and Mohamed Salim Salem, The Egyptian Renaissance Library, Cairo, 1957.

3. Chenity, Mohamed Bashir, Economic and Social Changes in Morocco during the Roman Occupation, National Book Foundation, Algeria, 1984.

4. Akoun, Mohamed El-Arabi, Economics and Society in Ancient North Africa, University Press, Algeria, 2008.

5. Worth, Charles, The Roman Empire, translated by Ramzi Abdo Girgis, Family Library, Cairo, 1999.

III. Foreign References and Article

1. Adam. J. La Construction Romaine 3ed., grand manuels Picard. S.D.

2. Alberteni, T., Actes de l'epoque vandal, Pairs, 1952.

3. Albertini, E., Documents d'epoque Vandale de couverts en Algerie, CRAI, 72, No. 3, 1928.

4. Billiard, R., la Vigne dans l'antiquite, Lyon, 1913.

5. Birebent, J. Aquae Romanae, Recherche d'hydraubique Romaine dans Est Algerien, Alger 1962.

6. Bloch, G., La Republique romaine, les Confilits Politiques et Sociaux, Paris, 1922.

7. Boissier, G., L'afrique Romaine, Hachette, Paris, 1907.

8. Bourgarel - Musso, A., Recharche économique sur l'Afrique Romaine, Revue Africaine, T. 75, 1934.

9. Brun J.P., Le vin et l'huile dans la méditerranée antique, Viticulture, oléiculteure et proceeds de fabrication édit. Errance, Paris, 2003.

10. Camps, G., Aux Origines de la Berberie, Massinissa ou les Debuts de l'Histoire, Libyca, 1962.

11. Carcopino, J. Le Marco antique, ed., Gallimard, Paris, 1948.

12. - Colonat Partiaire, in MEFR. XXVI, 1906.

13. — L'aptitude d'assimilation de Berberes á la Civilisation d'après L'histoire ancienne de Afrique du Nord, in VIII e congres Volte, 1938. 
14. — L'inscription de Ain Djemala, Melange d'archeologie et d'histoire, Pairs, 1906.

15. Carton, Dr., La Lex Hardiana et son commentaire par le procurateur Partruchus, revue archeologique Tom. 21, Mars-Avril 1892.

16. Chastagnol, A., La Legislation des biens des Villes au IVe Siecle á la Lumiere d'une Inscription d'Ephése, Attidell, Accad Romanistica Costantiniana 6 convegno intern, Perouse 1986.

17. Chevalier, R., la centuriation Romaine et la mise en valeur des sols aans la province d'Afrique, Geog 22 annee, Sept. - Oct., 1958.

18. Cognat, R., Inscription d'Henchir Mettich, CRAI, 41, No. 2, 1897.

19. Cuq, E., le colonat partiaire dans l'Afrique Romaine d'apres l'Inscription de Henchir Mettiche in: CRAI, No. 11, 1901.

20. Decret, F \& Fanter, M. L'Afrique du Nord dans L'antiquite des Orgines au Vosicle, Payot, Paris, 1981.

21. Gaukler, P., Enquête sur les les installations hydrouliques Romaines en Tunisie, Tunis, 1897-1912.

22. Gsell, S., Histoire ancien de l'Afrique du Nord, 1918-1928.

23. Hugoniot, $\mathrm{Ch}$, Rome en Afrique, de la chute de Carthage aux débuts de la conquite arabe, Coll. Champs Universite, Flammarion 2000.

24. Lacroix. F., L'Afrique Ancienne, Revue Afrique, vol. 14, 1870.

25. Le Bohec, Hisoire de l'Afrique Romaine 146 avat J.C. 439 Aprés J. C., Paris, 2005k.

26. Lecocq. A., Le commerce de l'Afrique Romaine BSGO, Tom. XII, 1932.

27. Leveau, Ph., A propos de 'lhuile et de vin en Afrique Romaine ou pourqoui deromaniser l'archeologie des compagnes d'Afrique, Revue pallas tom. 68, 2005.

28. Marcel $(\mathrm{Ch})$, Essaie de restitusion d'un moulin de l'époque Romaine à madaure (Constantine), Alger, 1930.

29. Maurice, S., et Tronoy, A., la Mediterranée antique IV, Siecle av. J. C., III.

30. Menuier (J), L'huilerie romaine de Kherbet-Agoub (Périgotiville, Bulletin de lasociété Historique et géographique de la region de Sétif, tome. II, (1941.

31. Mespoulet, M., L'inscription d'Ain Ouassel, Nouv, Revue Hist. De Droit francais, Mars-Avril 1892.

32. Mommsen, Th, Histoire Romaine, Trad. C. a, Alexandre, Paris, 1863.

33. Peuras, J. La potestas occupandi dans l'Afrique Romaine in: DHA vol. $25,1999$. 
34. Picard (Ch) et Rouge, J. Textes et documents Relatives a la vie economique et sociale dans L'empire Romaine, Paris, 1969.

35. Picard, (Ch), Neron et la ble. D'Afrique, Revue les cahiers de Tunisie, T. IV, 1956.

36. - La Civilisation de L'Afrique Romanie, 2 Edition, Paris, 1990;

37. Precheur Canonge, La Vie Rurale en Afrique Romaine, d'apres les Mosaiques, Paris sans date.

38. Saglio, E. et Autres, Dictionnaire des antiquités grecques et romaines, DAGR, Hachette, Paris, 1873-1919.

39. Saumagne, Ch., Inscriptions de Jean ez Zaytouna, in: CRAI 81, no. 4, 1937.

40. Slim, L et Bonifay. M., L'Usine de Salasion de Neapolis, Premiers resultats des Fouilles 1995-1998, Africa XVII, 1999.

41. Toutain, J., L'inscription d'Henchir Mettich, Unnouveau document sur la prapriete agricole dans l'Afrique Romaine, in: CRAI 1902.

42. Trabut (Dr.) l'Olivier en l'Algerie-Alger 1900.

43. Vel, A., Quelques inscriptions, RSAC, vol. 43, 1909. 


\section{التثريعات الزراعية وأثرها على ألثي

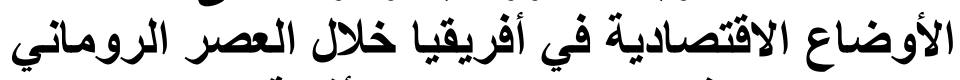

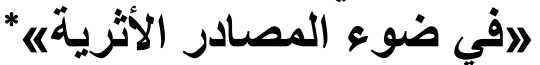

\section{د. سلمى محمد بكر هوساوي.}

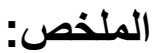

يقدم هذا البحث دراسة تحليلية نقدية للتنريعات الزر اعية في الولاية الأفريقيا

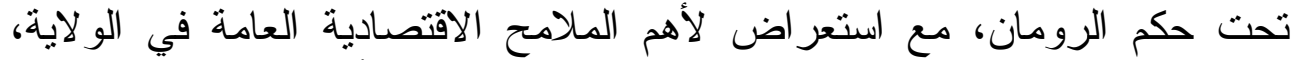
و الدور الذي لعبته السياسية الرومانية في تطوير الاقتصاد الأفريقي.

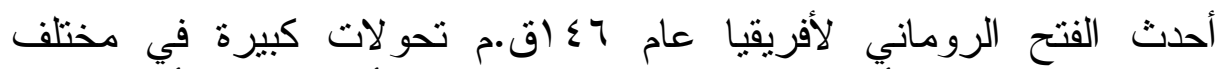

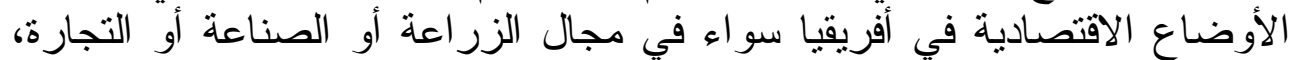

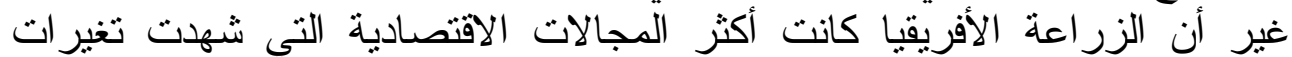

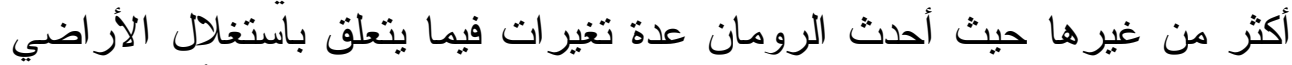

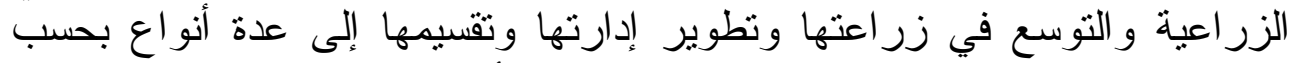

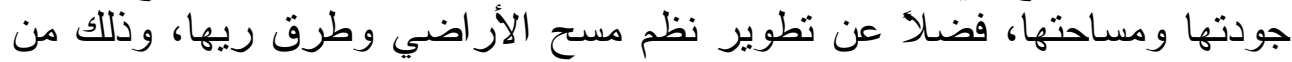

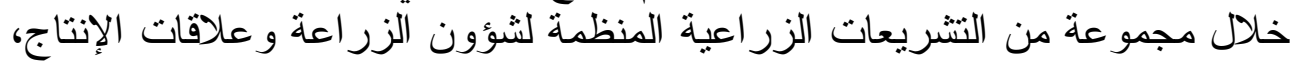

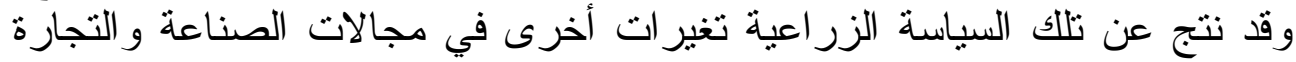
التي ارتبطت إلى حد كبير بالتطورات الزر اعية واعتمدت على التى منتجاتها بشكل

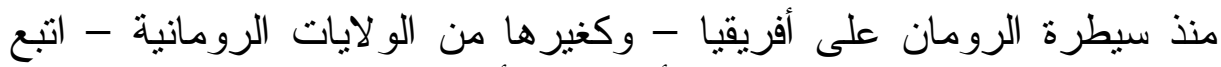

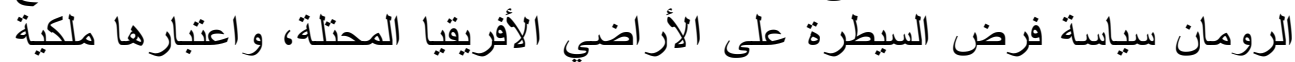

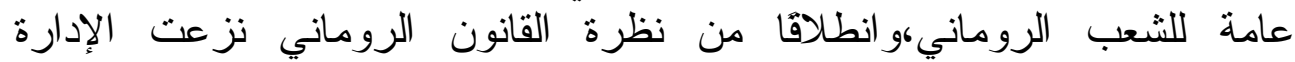

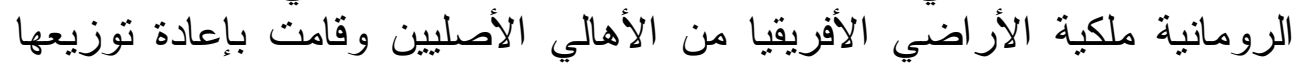

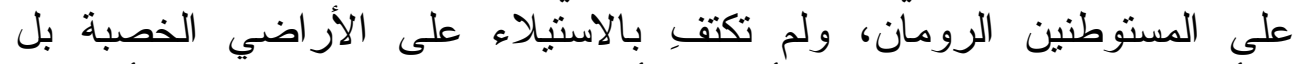

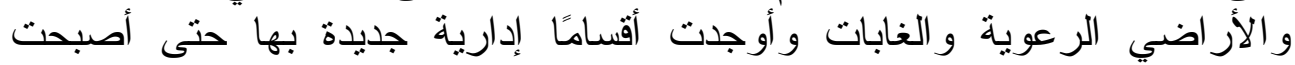

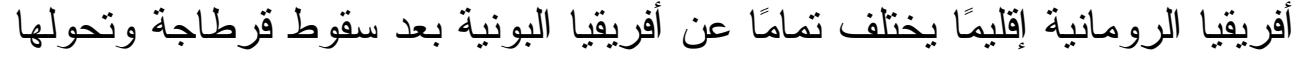
إلى السيطرة الرومانية.

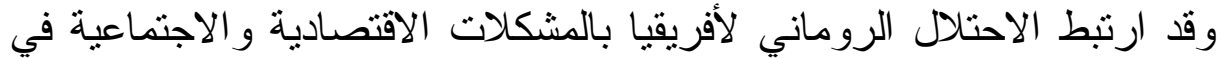
روما و إيطاليا وقيام حركة الإصلاح على يد الرماني لأخوين جر اكوس، حيث كانت الحركة

"جزيل الثكر والتقاير لعمادة البحث العلمي في جامعة الملك سعود لتمويل هذا العمل من خلال

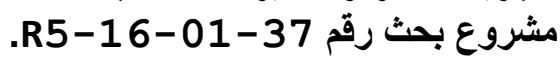
shosawi@ksu.edu.sa أستاذ مساعد/ قسم التاريخ - كلية الآداب/ جامعة الملك سعود 
الثعبية ترى في الاستيطان وتوزيع الأراضي على الفقر اء اللاتين و الإيطاليين حلا

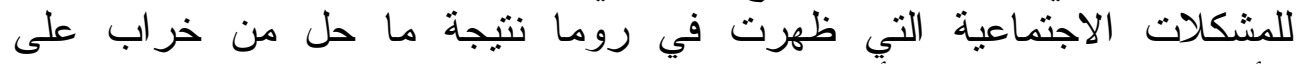

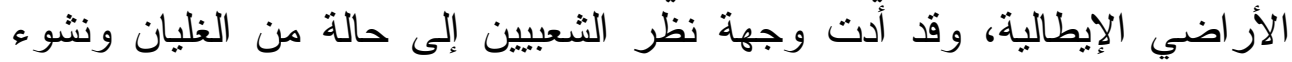

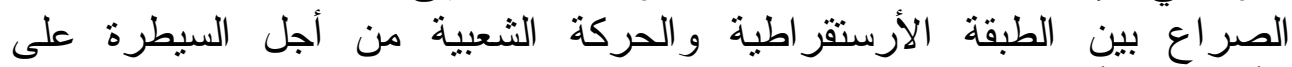
الأر اضي الأفريقيا.

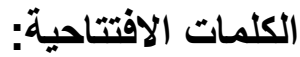
أفريقيا، الزراعة، قرطاجة،العصر الروماني، التتريعات، الاقتصاد، الزراعة،

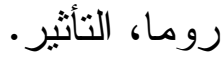

